\title{
Two Sides of the 1968 Legacy
}

\section{The Left between Postmodernist Escapism and Urban Guerillas}

\author{
Sergei M. Solovyov
}

\begin{abstract}
This article analyzes two responses by the Left to the turbulent events of 1968 in Europe and the failed attempt at revolution: the turn towards postmodern theory and the "minorities policy" is contrasted with the transition to urban guerilla warfare. The paper argues that the theoretical degradation of a considerable part of leftist thought after 1968 was a result of the transition to postmodernist attitudes. The article also analyzes the penetration of these trends into the concept of sociologist Immanuel Wallerstein, one of the most influential left-wing theorists. The article traces the logic behind the emergence of urban guerillas in Europe and the causes of their defeat. By analyzing both the postmodern and ultra-radical experience, the author offers some conclusions regarding the current situation and the future of Europe's Left.
\end{abstract}

\footnotetext{
Sergei M. Solovyov, Ph.D. in Philosophy

Faculty of Political Science; Lomonosov Moscow State University, Moscow, Russia

Leading Researcher

Russian State Archive of Social and Political History (RGASPI)

Chief Specialist

Editor of 'Scepsis', journal of science and social criticism (scepsis.net)
}

ORCID: 0000-0003-4708-8516

e-mail: solosm@mail.ru

Mailing address: Moscow State University, Lomonosovsky avenue, 27 k.4, 119192, Moscow

Acknowledgements to Alexander Tarasov and Pavel Tkachov, who at a certain point briefed the author on little-known aspects of the history of Western left-wing radicalism in the 1960s-1980s, and to Miron Tretyakov for advice shared during the work on this article. 
Keywords: social philosophy, 1968, Immanuel Wallerstein, world-system analysis, revolution, postmodernism, left radicalism, urban guerilla, RAF

The legacy of 1968 is still in the focus of public debate. The recently marked 50th anniversary of the "student revolution" is not the sole reason, since the following also continues to draw attention: the wholesale politicization of student youth in a seemingly calm and prosperous Europe, anti-capitalism as a cultural norm, and changes in the education system. From the standpoint of cultural change, the events of 1968 are considerably ahead of our times. For example, the crisis in the traditional family had begun before 1968, but it was in the late 1960s that the old patriarchal family model began to fade into the past. This article primarily addresses politics, rather than culture; above all, the political and theoretical consequences of 1968 for the left-wing movement and leftist thought.

It is an undeniable fact that the events of 1968 largely determined the cultural transformations of the last three decades of the 20th century (Hobsbawn, 1995, pp. 331-335), yet their political consequences still fuel debate. In the last volume of his ambitious tetralogy Sources of Social Power, historical sociologist Michael Mann does not mention the events of 1968 (or Western Europe as a whole) (Mann, 2012), while Immanuel Wallerstein attaches key importance to both (Wallerstein, 1996, p. 170). For the left-wingers, 1968 became an essential part of the basic myth, an opinion shared by a certain segment of the liberal establishment and incorporating some former leftists (Joschka Fischer, Daniel Cohn-Bendit, and many others).

This article's main argument is that 1968 was a grave historical defeat for Western (in the first place) European left-wingers organizationally and, still worse from the standpoint of long-term effects, theoretically. The task of this article is to highlight two important phenomena that do not fit in with widely spread misconceptions concerning 1968: a theoretical and ideological crisis of the Left, and an ultra-radical attempt to overcome it.

In connection with the terminology used below it is essential to make one important remark. The term 'Left' has turned out to be very 
useful-it is devoid of specifics and implies a very abstract political tinge. It might seem everybody knows who the Left are, but this term may be easily applied to different, even antagonistic, phenomena. One of the effects of 1968 in theory and in politics is that the notion 'Left' was gradually emasculated and drained of specific content, which made it even safer, in the New Left's parlance, for the capitalist system. Therefore, attempts to come up with a precise definition of what the Left means have proven futile, since this term may denote a critical attitude towards authoritarianism, an unrestricted free market (but not necessarily capitalism), government dictatorship, and oppression. This may sound too abstract, but the meaning of the term 'Left' is so vague that any more concrete wording will leave out a number of political structures, movements, and personalities that identify themselves as left-wingers.

\section{CARE OF THE SELF VS TRUTH}

The left movement in Europe in the late 1960s culminated in 1968, only to subside in the early 1970s. During that decade, neo-liberalism emerged as the indisputable winner in the ideological struggle and state economic policy: first in Chile, and then in the core countries, such as Britain and the United States (Harvey, 2007, p. 39-63). With the breakup of the Soviet Union, neo-liberalism's victory over the Left looked final.

A large share of left-wingers-mainly traditional Social Democrats and Eurocommunists, as well as student protest activists-were more or less successfully incorporated into the existing system, thus abandoning most or all of their fundamental political demands and principles. This fast U-turn away from struggle and the recognition of their defeat after all the political battles of the 19th century and first two-thirds of the 20th century should be attributed not only to the erosion of the industrial proletariat, the Left's traditional base, but also to the theoretical degradation of the left movement.

Prerequisites for an escape from reality can be found in works written by left-wing theoreticians prior to 1968. Long before Michel Foucault's late works, Raoul Vaneigem, one of the founders of Situationism, had arrived at the conclusion that hedonism was 
necessary as a means of struggle against capitalist alienation- "people serenely enjoying the pleasures of the senses" (Vaneigem, 2001, p. 255). This principle is placed outside any historical context; it offers another apology for the sexual revolution, satirized by traditional Marxists, in particular, historian Eric Hobsbawm (Hobsbawm, 2007, pp. 284-288). This principle was used as a basis for the radical subjectivity of the Situationist International. At the end of this book Vaneigem offers a standard list of anarchist principles: no organization, no hierarchy, and ever-lasting revolution in everyday life (without explanation). The book contains mantras capable of attracting some of the youth, but has little to do with any analysis of reality: "The barbarity of riots, the arson, the people's savagery, all the excesses which terrify bourgeois historians, are exactly the right vaccine against the chill atrocity of the forces of law, order and hierarchical oppression" (Vaneigem, 2001, p. 242).

Some students liked this Nietzschean rhetoric, but it was unable to fuel their enthusiasm for long or be transformed into political action (Hobsbawm, 2007, pp. 341-343).

Works by the Situationists' other leader Guy Debord are more systemic, but they also brim with verbal radicalism and naïve anarchism. For instance, Debord traditionally accuses the Bolsheviks of becoming a group whose profession is "the absolute management of society," without saying a word about what else they should have been doing in the realities of 1917 and the Civil War. Debord's general conclusion is this: "In a certain sense the coherence of spectacular society proves revolutionaries right, since it is evident that one cannot reform the most trifling detail without taking the whole thing apart" (Debord, 1990 , p. 80). But this conclusion turned out to be very far from reality. The Green movements, where many of the 1968 protesters eventually migrated, the feminist movement, and the struggle for LGBT rights indicated that there where reform does not threaten capitalism as such, it can be implemented and even nicely blended into the "spectacle." The Situationists' ideas might have been disregarded altogether, but while the Situationist International by itself remained a group of marginal personalities, its founders quite accurately expressed the sentiment of a rather large group of protesters. 
The delusion that the "spectacle" was comprehensive played a nasty trick on the 1968 intellectuals. In a certain way (rather odd initially, but in reality, quite logical) it considerably facilitated their embedding in the System. At the end of his life Debord stated quite fairly, though, that "the society of the spectacle transformed the revolt against it into a spectacle." The root cause of the problem is that the protest itself had largely been a spectacle from the outset. In reality many revolutionary acts had certain traits of a show or even carnival. Indeed, it is enough to leaf through the recollections of events in 1905 or 1917 in Russia. But the spectacle in real revolutions was just an element of in-depth processes and by no means a self-sufficient phenomenon. It is quite obvious that no spectacle can overpower any system.

Boris Kagarlitsky (2017) said quite correctly that postmodernism in the form of "incredulity towards metanarratives" (Lyotard, 1984) came in handy for those intellectuals who were in dire need of reconciling their careers under capitalism with their youthful passions. Moreover, postmodernism in fact was tantamount to a categorical and aggressive denial of the very idea of reforming society-of a comprehensive project for its reform. What was proposed instead? Foucault offered a clear answer in the title of one of his final books, Care of the Self, which in fact provided the reason for giving up political struggle for escapism. Escape into the private life, including alcoholism and drug addiction (The fate of Guy Debord, who suffered from alcoholism, is quite significant in this respect), or the outspokenly cynical stance of the intellectuals, who, well aware of the vicious and exploitative nature of capitalist society, are prepared to put up with it on the condition of personal benefit. This cynical attitude as the main parameter of the modern ideological situation was examined in Slavoj Žižek's first work The Sublime Object of Ideology: "This cynicism is not a direct position of immorality, it is more like morality itself put in the service of immorality-the model of cynical wisdom is to conceive probity, integrity, as a supreme form of dishonesty, and morals as a supreme form of profligacy, the truth as the most effective form of a lie.... The cynical reaction consists in saying that legal enrichment is a lot more effective and, moreover, protected by the law" (Žižek, 2008, p. 26). 
This cynicism is a direct consequence of the ideological deformation that followed the post-modernistic reflections on the defeat of the Left after 1968.

In turn, this stance assumed by the intellectuals was behind their shrinking role in politics. Whereas before the late 1980s intellectuals often played the role of the political opposition, in later years they gave way to show business celebrities, largely because they had abandoned their mission of enlightenment (and, of course, due to the neoliberal depoliticization, which grew particularly strong after the collapse of the Soviet Union) (Hobsbawm, 2017, pp. 241-243). The phenomenon of "Marxism without the proletariat" - intellectuals who were losing ties with concrete political practices-manifested itself in the prewar years. On the eve of 1968 it "lost the nerve" of its relevance, the concrete nature of a revolutionary alternative to capitalism (Dmitriev, 2004, p. 477). Its link with the mass working-class movement was lost, while rioting students were an unworthy substitute. While in the early 1960s the political and enlightening mission of the intellectual looked extremely important, then today the intellectual is simply part of the "middle class." In 1961, Marxist economist Paul Baran wrote: "The more reactionary a ruling class, the more obvious it becomes that the social order over which it presides has turned into an impediment to human liberation, the more its ideology is taken over by anti-intellectualism, irrationalism, and superstition. And by the same token, the more difficult it becomes for the intellectual to withstand the social pressures brought upon him, to avoid surrendering to the ruling ideology and succumbing to the intellect workers comfortable and lucrative conformity. Under such conditions it becomes a matter of supreme importance and urgency to insist on the function and to stress the commitment of the intellectual. For it is under such conditions that it falls to his lot, both as a responsibility and as a privilege, to save from extinction the tradition of humanism, reason, and progress that constitutes our most valuable inheritance from the entire history of mankind" (Baran, 1961). In the era of postmodernism and neoliberalism, these words looked hopelessly outdated. In recent years, though, attempts have been made to restore the leftist intellectuals' status and responsibility stemming 
from the enlightenment tradition, precisely in the capacity of crusaders against the effects of postmodernism and neoliberalism.

In this connection it is worth recalling an excellent book by Alan Sokal and Jean Bricmont called Intellectual Impostures, which is a must-read for anyone who wants to understand and expose postmodernism. The book was written after the fabulous Sokal affair in 1996, when Sokal, a mathematician and adherent of left-wing views, submitted a deliberately absurd article to a well-established postmodernist magazine. The editors gave an enthusiastic welcome to the proposed hoax. The book demonstrates the utter absurdity of the postmodernist discourse by means of scientific consideration of the terminology used by Gilles Deleuze, Felix Guattari, Jacques Lacan, Jean Baudrillard, and their followers. The authors view postmodernism as "a vulgate that mixes bizarre confusions with overblown banalities." They stress that apart from everything else irrationalism resulted in left-wing intellectuals abandoning political commitments or turned them into "servile advocates" of capitalism (Sokal and Bricmont, 2003, pp. 197-198). Although they say at the very beginning that "the target of our book is epistemic relativism, namely the idea... that modern science is nothing more than a 'myth', a 'narration' or a 'social construction' among many others" (Sokal and Bricmont, 2003), the authors tear apart the entire method of postmodernist philosophizing. It is noteworthy that both authors position themselves as leftists; more precisely, as Old Leftists. In his afterword to the hoax Sokal wrote: "I confess that I'm an unabashed Old Leftist who never quite understood how deconstruction was supposed to help the working class. And I'm a stodgy old scientist who believes, naïvely, that there exists an external world, that there exist objective truths about that world, and that my job is to discover some of them" (Sokal and Bricmont, 2003, p. 249).

In 2018, Sokal's trick was repeated. A number of science magazines agreed to publish ostentatiously absurd articles allegedly concerning gender theories, fabricated by James Lindsay, Helen Pluckrose, and Peter Boghossian in strict conformity with the correct ideological commandments. It was a fresh confirmation of the degradation of the humanities (Lindsay, 2018). All subsequent efforts to present 
some sort of excuses-and there have been quite a few of them-were nothing more than attempts to mask the obvious. Science magazines agreed to publish preposterous nonsense for the sole reason that this nonsense fitted in with a system of certain ideological expectations. It was in no way different from the publication of senseless texts supplied with a list of references to the "classics of Marxism" and resolutions by the latest Communist Party congress in official Soviet magazines. Naturally, falsifications can be found in natural science magazines, too. But pseudo-science (in this particular case parascience) became so widely spread in humanitarian surveys precisely because the postmodernist turn resulted in the deliberate discrediting of the principles of distinguishing between real science and non-science.

Discrediting the notions of truth and science through the process of attaining it-with all the necessary reservations made concerning the distinctions between the humanities and natural sciences, the "theoretically laden facts," and inevitable bias of scientists-leads to the degradation of science. Additionally, this leads to the severing of its bonds with reality and the proliferation of outspoken charlatanism in the mass media, on book shelves, and in well-respected science magazines. Either science is in search of truth, meaning it is possible to hold thoughtful discussions regarding the process on its merits, or science mutates into scholasticism and a purely commercial enterprise, which has nothing to do with either expanding humanity's knowledge or with public benefit. Such a turn is often associated with "leftist" thought, which defends the rights of minorities and denies the comprehensibleness of truth with mandatory references to Foucault, Barth, Lyotard, Baudrillard, and other postmodernists, but at the same time continues to persistently quote Marx and even Lenin (Jameson, 2008, pp. 71-72, 203-206).

This transformation of revolutionary theory into a quite harmless text has turned out to be a far better method of struggle with Marxism than a direct ban.

However, the point at issue is not the sterility or helplessness of postmodernist gnoseology, although the rejection of truth as a manifestation of "domination" was tantamount to a refusal to delve into the social reality, while commitment to science, in contrast to utopia, has 
been identified as the Left's main advantage since Marx formulated his theory. The postmodernist Left is unable to provide an answer to the question of how it is possible to hope for victory in the struggle against the System with only the minorities to rely on, as Marcuse postulated in his One-Dimensional Man (Marcuse, 2007, pp. 260-261) and which was echoed by Foucault and Deleuze and their followers. While minorities were certainly entitled to obtain their rights, that could happen and did happen within the capitalist system. There was nothing very revolutionary about that. The same happened to another group that surely cannot be called a minority-women. Feminism in the West largely triumphed without dismantling the capitalist system (albeit with major reservations; for instance, the female body remains a sexual object in mass culture). Capitalism has reconfigured itself. In some cases, the reconfiguration was painful, but it succeeded. This happened, though, only in the core capitalist states, for most residents of the countries of the "golden billion," while the rest of the world remains a scene of extreme savage exploitation, of women's labor in particular, though some transitional forms do exist. In European countries labor migrants are subject to great exploitation. Oddly enough, such a comprehensive vision of capitalism is impossible for many of those of the Left.

The brief history of the anti-globalist movement is very telling in this respect. In their heyday, the anti-globalists enjoyed the support of tens of millions of people. A variety of political forces mobilized their efforts to take part in the struggle against transnational corporations and governments protecting their interests. But the decision to refrain from setting concrete political aims and from the power struggle, prompted by the "traditions" and ideals of the 1968 revolution, promptly pushed the movement into stagnation. Moreover, very soon it turned out that the interests of anti-globalist groups in the "golden billion" countries and former Eastern Bloc member-states, Africa, and Latin America were very different (Tarasov, 2008a). This distinction was an effect of class differences that remained unexplored and ignored by most anti-globalist leaders and participants in the movement. It is rather significant that within its framework quite a number of excellent works emerged devoted to analyzing and criticizing neoliberalism. 
However, no theoretical studies were conducted that went beyond these bounds either in the field of politics or the economy. No conclusions were drawn from an analysis of neoliberalism, except for the universal humanistic conclusion that it is essential to eliminate this system as a threat to life on the globe itself. Although this period saw research within the framework of world-system analysis and the concept of peripheral capitalism, these theories had emerged long before anti-globalism. Due to the absence of a political program, a lack of vision of organizational prospects, internal rifts, and squabbles the anti-globalist movement had disgracefully sunk into oblivion by 2010. The reason for this (alongside other factors) was the uncritical adoption of the worst part of the "1968 legacy" - the repudiation of hierarchy in organizational work and the struggle for power. It is no accident that the rise of right-of-center populist movements is so strong in Europe and the United States (for instance, the Alternative for Germany, the National Front in France, etc.) because they take up the niche voluntarily vacated by the Left (Kagarlitsky, 2017, p. 73). This is noticeable not only when analyzing electoral successes, but in studying the concepts that serve as a guide (although indirectly) for left-wing politicians and many leftists theoreticians.

\section{WALLERSTEIN CASE}

American sociologist Immanuel Wallerstein is one of the most notable left-wing thinkers today and his views are the clearest example of mythologizing 1968. Based on a synthesis of components of Marxism, theories of dependent capitalism and peripheral capitalism, as well as Fernand Braudel's views in the past two decades, Wallerstein's worldsystem analysis played the same role for many leftist theoreticians that orthodox Marxism did in the first half of the 20th century. An analysis of his concept is of great interest because it illustrates how non-critical idealizing of the 1968 legacy breeds endless contradictions within the theory itself and leads to its ideologization, which, in turn, calls into question the trustworthiness of the concept as such.

According to Wallerstein, the 1968 revolution was the second truly global revolution after the European upheavals of 1848. As is known, 
both revolutions failed. Moreover, both had far weaker influence on countries outside Europe than the French Revolution in the late 18th century and the Russian Revolution of 1917, which had a tremendous impact on many countries on different continents.

Wallerstein argues that the strategic striving for political power was the major mistake nearly all opponents of capitalism made up to the middle of the 20th century, of all anti-systemic movements, as he calls them. Shortly after coming to power, those politicians discovered that the capabilities of the state within the world-system were limited. It turned out that the seizure of power (revolution) was nothing more than a reform of the system. "Generally speaking, rebellion as a technique has worked only at the margins of central authority, particularly when central bureaucracies were in phases of disintegration" (Wallerstein, 1996, p. 66.).

Wallerstein ignores the experience of bourgeois revolutions. $\mathrm{He}$ interprets them only as varieties of "inter-bourgeois struggle," as well as the experience of working-class movements (including uprisings) in Europe and the United States in the 19th century. According to Wallerstein, the capitalists themselves proposed concessions to the working class for the sake of keeping the system stable: if he is to be believed, the latter is a self-regulatory entity. He emphatically denies the concessions earned after a hard-fought struggle. According to Wallerstein, under capitalism "the social disruption undermined placatory modes of socialization. All in all, therefore, the motivations to rebel were strengthened, despite the fact that the possibilities of success were perhaps objectively lessened" (Wallerstein, 1996, p. 66). Historians do not know of a single successful uprising of the lower classes in the pre-capitalist era that changed the image of the world-system as dramatically as the revolutionary movements of the 19th and 20th centuries. Wallerstein not only makes a crude historical mistake (in fact, a distortion), but he also retrospectively projects the defeat of 1968 to all other past and future revolutionary movements. Thus, he naturally arrives at a pessimistic conclusion regarding their opportunities.

He recognizes as a positive experience only those anti-systemic movements that refrained from coming to power and exerted 
influence on undermining the political stability of historical capitalism contrary to those which "strengthened the system" by taking power (Wallerstein, 1996, p. 70). It turns out that the October Revolution of 1917 and, for instance, the war in Vietnam, if Wallerstein is to be believed, did not undermine the stability of the capitalist system. What factual proof can be provided for the desire to accumulate capital in Russia after the October Revolution? Wallerstein ignores the problem of the means of production and class relations within a country and offers generalizations that in fact reduce the value of his analysis to nothing. It goes without saying that the Socialist bloc had nothing to do whatsoever with Marx's socialism, where there should be no place for classes, exploitation, and, in the final count, the state. But this is not a reason to regard it as capitalist! Wallerstein is keen to demonstrate that anti-systemic (revolutionary) movements agreed to be plugged into the logic of capital and failed to go beyond the bounds of the world-system. For this reason, Wallerstein declares the Soviet bloc countries capitalist in defiance of a tremendous amount of facts, because, he says, they were connected with the capitalist world-system; in other words, they preserved economic relations with the rest of the world. This postulate does not hold water either theoretically or from the factual viewpoint.

This historical absurdity occurs because Wallerstein completely ignores the fact that the countries taken outside the capitalist framework (albeit not into socialism) forced it (capitalism) to change, to become more social, to create the welfare state; in a word, to reform itself (Hobsbawm, 1995, p. 84). He forgets that capitalism's goodnatured disguise was gone as soon as neoliberalism triumphed after the fall of the Soviet system.

According to Wallerstein, anti-systemic movements were wrong not only because they sought power. They were wrong also because they relied on the prevailing ideology of the accumulation of capital. From Wallerstein's point of view this ideology is universalism: "The belief in universalism has been the keystone of the ideological arch of historical capitalism" (Wallerstein, 1996, p. 81). Wallerstein understands universalism as three different things he blends into one. Firstly, it is the ideology of modernization, linked with the idea of 
progress (linear progress, I should add), which subjugated anti-systemic movements, too, and cloaked them in the ideological garb of the Enlightenment. Secondly, the idea of universal culture, in fact, cultural imperialism, which particularly inspires the "support apparatus" of the accumulators of capital-the middle class, the "meritocracy," which, according to Wallerstein, accounts for $15-20$ percent of the beneficiaries of capitalist expansion, alongside the entrepreneurs. Thirdly, there is "a set of beliefs about what is knowable and how it can be known. The essence of this view is that there exist meaningful general statements about the world-the physical world, the social world - that are universally and permanently true, and that the object of science is the search for these general statements in a form that eliminates all so-called subjective, that is, all historically-constrained, elements from its formulation. [...] It requires not merely respect but reverence for the elusive but allegedly real phenomenon of truth. [...] Our collective education has taught us that the search for truth is a disinterested virtue when in fact it is a self-interested rationalization. [...] The search for truth, proclaimed as the cornerstone of progress, and therefore of well-being, has been at the very least consonant with the maintenance of a hierarchical, unequal social structure in a number of specific respects" (Wallerstein, 1996, p. 81-82). The above quote, just as the comparison of the search for truth with a narcotic drug, is capable of not just devaluating everything the author seeks to prove (naturally, Wallerstein fails to do so consistently, otherwise what is the use of his own world-system studies?). Recognizing the omnipotence of ideology, the presence of ideology in all spheres of life, including language (which poststructuralism proclaims), and science are imprints of the 1968 defeat, which did not trigger the crisis of capitalism, but, on the contrary, of leftist thought, by disarming it and steering it into a postmodernist dead end.

Wallerstein uses the following as one of the proofs of the existence of this universalist ideology, where all distinctions between conservatism, liberalism, and left-wing radicalism are lost: Once two practices, racism-sexism and universalism, gained strength simultaneously, they were to be essentially interconnected. Simultaneousness is a weak 
argument for claiming that the phenomena are uniform. The use of analogies in the capacity of arguments is a trick Wallerstein resorts to frequently in his works, not to mention the fact that he is historically incorrect again: racism as an ideology emerged at the end of the 18th century in response to abolitionism, while women in patriarchal families were exploited from the very beginning of class society.

The only way out of the dead end of universalism Wallerstein can offer after the postmodernists is the involvement of marginal groups and minorities in anti-systemic movements (Wallerstein 1996, p. 90). But how this can lead to victory over the comprehensive system of accumulation remains unclear. It is hoped that the system itself is undermining its basis before our eyes and the process of "commercialization of everything" is nearing completion. This means that the capitalist world-system will soon exhaust itself. Whereas in accordance with orthodox Marxism and neo-Marxism of the 20th century, in the process of its development capitalism was forced to breed contradictions in all spheres of life, Wallerstein points, in fact, to only one purely economic contradiction: the logic of accumulating capital is exhausting the zones that once acted as its periphery, thus paving the way for its own crisis.

Wallerstein equalizes ethnic and gender contradictions with class ones, although his own analysis indicates that sexism and racism are consequences (essentially and chronologically) of class relations within the capitalist system. At this point we come across a certain part of the ideological legacy of 1968 with which Wallerstein associates himself. In this particular case, he repeats the conclusions formulated by Chantal Mouffe and Ernesto Laclau in their work on the equality of different social oppositions under capitalism: gender, class, ethnic, etc. (Laclau and Mouffe, 1985). The main fact that Wallerstein and his adherents are reluctant to recognize is that capitalism has managed to give rights to minorities after 1968 and survive, and that the struggle of minorities has by no means harmed its viability. Now one can postulate with certainty that those leftists who borrowed the "minorities policy" from the 1968 legacy to make it their weapon of choice, which in the field of theory was closely connected with postmodernism, have now found themselves in a dead end and are quickly ceding positions to 
both neoliberals, who have just privatized the same agenda, and the rightists. Both the theoretical and political failures (a whole string of his failed forecasts is a vivid confirmation of this) of Wallerstein's theory indicate that the "anti-universalist" legacy of 1968 plays well in academic auditoriums, but does not work either as a tool for studying society or as a political program.

\section{EUROPEAN URBAN GUERILLAS: HEADING FOR THIRD WORLD}

A number of participants in the 1968 events have established themselves quite successfully within the capitalism system. In fact, their radicalism turned out to be adolescent and temporary. Some of them turned their backs on the ideas of their youth and drifted to the right, occasionally as far as neoliberalism (the most noticeable examples are Andre Glucksmann, Bernard-Henri Levy, Joschka Fischer, Daniel Cohn-Bendit, Michel Rocard, etc.). Some joined the existing left-wing political forces (mainly the Communist parties), while others were preserved in relatively small radical political groups (Trotskyist, for instance), which also laid claim to participation in traditional politics. Alongside the "minorities policy" and various ways of becoming embedded in the parliamentary system at the cost of losing one's own political identity, there was another track for leftist ideology to develop after 1968. It attracted far fewer followers but enjoyed far greater influence than it may seem today. Left-radical militant groups sprung up professing urban guerilla tactics. The members and supporters of these groups tried to move the neo-colonial wars from the "third world" into the first in strict conformity with Che Guevara's motto: "Create two, three, many Vietnams!" One of the leaders of the French group Action Directe wrote in the 2000s after serving a 25-year prison term: "By taking this anti-authoritarian stance we broke with those who then were called the 'Old Left' (parliamentarians and revisionists) and the 'New Left' (integrated with the system, split into small groups, law-abiding and pacifistically minded). We resolutely did away with the bourgeois forms of political activity" (Rouillan, 2013). They tried to return war to the cities of the metropolitan powers, from where, in their opinion, it had been exported to the "third world." With this 
in mind they unleashed combat operations in the cities of Germany, Italy, France, Belgium, and other countries. But it took those people a long time to make this decision.

Several events in the "third world" had a tremendous influence on the European radicals: the revolution in Cuba, which occurred without the intervention of the Soviet Union, the overall rise of the revolutionary movement, the war in Vietnam, and the Cultural Revolution in China, interpreted as the youth's merciless crackdown on the government bureaucratic machinery. These events served as a catalyst and an action guide; hence the popularity of Mao, Che Guevara, and Fidel Castro with the leaders of the revolt of the 1960s and the attempt to borrow from the third world the organizational forms of struggle: from assemblies to urban guerilla warfare. Ultra-radical leftist groups used as their guide the Minimanual of the Urban Guerilla, written by Brazilian Communist Carlos Marighella (Marighella, 2002), and Mao's works concerning the tactic of guerilla warfare.

What made the radicalization of students in the late 1960s still more surprising for the authorities and traditional parties was that it occurred amid strong economic growth, although a recession would follow in the 1970s. Harsh repressive measures, such as expulsions from universities, disciplinary bans, police crackdowns on assemblies and rallies, and arrests, made some of the young radicals (including students) still more certain about the correctness of leftist radical ideas to destroy the entire capitalist system. At the same time, the authorities interpreted everything as a "Communist threat," even relatively calm peace initiatives by pacifists and opponents of the nuclear arms race, ecologists, and campaigners for the rights of minorities. Accordingly, these groups received rough treatment, which pushed the youth still farther into radicalism.

This process of forcing the out-of-parliament youth opposition from the political scene occurred in nearly all Western countries: France, Italy, Spain, Portugal, and the United States. In Germany it was more noticeable than elsewhere.

West Germany in the 1960s was not a prosperous democratic welfare state. At that time, West Germany was a country where Nazism 
and the Nazis were not bygone yet, where the opposition was in fact non-existent and where power was distributed within the "political parties' oligarchy." Under pressure from the Christian Democratic Union (Adenauer said outright that the Social Democrats were a menace to statehood) and subject to bullying by Axel Springer's yellow press publishing house, the Social Democratic Party of Germany steadily mutated into a purely formalistic group, "Her Majesty's Most Loyal Opposition."

A handful of three parties - two main ones and the tiny Free Democratic Party-played the parliamentary elections game repeatedly, with a large share of the media remaining under the control of the "blacks" - the Christian Democratic Union/Christian Social Union. The nomination of candidates proceeded under the total control of top party functionaries. Any manifestation of dissent resulted in the expulsion of troublemakers. In politics, former high-ranking Nazis called the tune. Chancellor Adenauer's adviser Hans Globke was one of the authors of race laws; Kurt Kiesinger, Germany's grand coalition-era chancellor, occupied a senior position in the Foreign Ministry's broadcasting department under Hitler; and other senior Nazis held posts in the judiciary, the army, and industry. The Extra-Parliamentary Opposition resisted attempts to introduce emergency legislation in Germany that would cancel democratic rights, stood up against the Bundeswehr's participation in the Vietnam War, against U.S. bases in German territory, and against the participation of (neo)Nazis in politics, and advocated respect for the West German Constitution. Incidentally, in 1968-1969 it was the Extra-Parliamentary Opposition and Germany's intellectuals who staged mass protests to quash an attempt by neo-Nazis from the National-Democratic Party to become a parliamentary party and join the CDU/CSU as its right wing. In the longer term, protests by young people and intellectuals forced German society into painful deliberations over Germany's guilt and responsibility for the crimes of the Third Reich (Kyonig, 2012, p. 29).

The Socialist German Student Union (Sozialistischer Deutscher Studentenbund (SDS)) and its periodical Konkret magazine were the 
center of out-of-parliament opposition. Despite their activity, the Extra-Parliamentary Opposition's youth were not taken seriously either by the authorities or the "official opposition" represented by the Social Democratic Party of Germany (SPD). Moreover, the SDS was becoming ever more radical and the SPD expelled them in 1961 (Konkret magazine had lost the party's support one year earlier). The Socialists found the too "resolutely-minded" young allies scary. The Communist Party preferred to distance itself from them as well. The youth was critical of the Soviet Union, while Moscow had no leverage to control the SDS and, respectively, saw it as a threat. Springer's proCDU media bullied the Extra-Parliamentary Opposition as strongly as Nazi propaganda would have done. Finally, a brainwashed neoNazi killed SDS and EPO leader Rudi Dutschke in 1968. The police displayed far greater zeal in struggling with left-wing demonstrators than with the neo-Nazis (Catholic student Behno Onnezorg, a casual passer-by, was shot in the back and killed by a policeman during a crackdown on demonstrators in 1967) (Tarasov, 2003).

Radically-minded young people reacted to this not as a casual death, but as a logical outcome of police brutality and slander. In response to protests by students and the Extra-Parliamentary Opposition against the war in Vietnam, against Nazis in the country's leadership, against emergency laws, and against nuclear arms, police violence continued to grow and Springer's media empire unleashed a real war on the anti-Nazis. In West Germany, ostensibly democratic but not really democratic, there was no place for the Extra-Parliamentary Opposition. The political scene was already distributed. A majority of the population felt no fear of losing political freedom, but was really afraid of losing living standards and jobs (Jaspers, 1969, p. 186). Radical youth seeking democracy at the end of the 1960s realized that although the institutions of democracy were in place, they did not work.

In the end many young advocates of the German Constitution arrived at the conclusion that it was a fake, that fascism was on the verge of seizing power in Germany again, that "fascism must be lured out," and the fascist state must be forced to demonstrate its nature by means of 
armed struggle. Very soon a leftist radical terrorist organization called the Red Army Fraction (Rote Armee Fraktion) emerged on the scene.

In 1965, Karl Jaspers, a humanist and representative of the religious version of existentialism, published a book highly critical of Adenauer's Germany. The following year, replying to his opponents, he formulated his ideas in far harsher terms. Articles written by Konkret's leading columnist and RAF leader Ulrika Meinhof from the collection From Protest to Resistance (Meinhof, 2004), published in Russia, in many respects repeat the ideas of Jaspers's book Wohin treibt die Bundesrepublik (The Future of Germany) (Jaspers, 1967). In 1966, the position of elderly and conservatively minded philosopher Jaspers differed from the views of the young journalist Meinhof in two respects-it was more systematic and, odd as it may seem, more radical. Jaspers said about the situation in West Germany: "If the republican way of self-persuasion and of the events' development as a result of conversations and debates between forces struggling with legal methods is eliminated, if politics is terminated in the full sense of the word, then there remains only selfdenial or civil war. [...] The people who in this case will not prefer civil war to the absence of freedom is not a free people" (Jaspers, p. 43). During the peak of RAF activities in 1977, Heinrich Boll, a well-known German author and supporter of dissidents persecuted in the Soviet Union (and who propagated Lev Kopelev's and Aleksandr Solzhenitsyn's works among European audiences), all of a sudden declared that it was necessary to complement the school program with Meinhof's play Bambule (finalized shortly before its author went underground), and all of her printed works dating back to the pre-RAF period should be made must-reads (Boll, 1996, p. 561). Clearly, Boll, Gunther Grass, Siegfried Lenz, and many other German authors who campaigned for the rights of arrested RAF activists could hardly be suspected of bloodthirstiness or immorality. German intellectuals realized that leftist terrorism was a direct result of keeping the radical opposition outside the political system and of refusing to turn an attentive ear to it in the legal political space. They also realized that the struggle against terrorism was conducted through utterly illegal and anti-democratic methods reminiscent of the fascist regimes. 
The RAF is only one of the left-wing terrorist organizations. In Germany alone there were the 2 June Movement, the Tupamaros West Berlin, the Revolutionary Cells, etc. Next to the RAF in terms of publicity were Italy's Red Brigades. At the end of the 1970s and early 1980s, the Action Directe existed in France and Communist Combatant Cells were active in Belgium. There was an armed radical leftist group in peaceful Denmark. However different their ideologies and practices, the very fact that such organizations emerged was a telling symptom. Their activity subsided in the second half of the 1980s, but the last RAF generation gave up armed struggle only in 1994.

The working-class movement demonstrated an upsurge in the United States in the wake of non-system youth protests in Germany, France, and Italy. Legal trade unions and the working-class movement in general joined the student movement to realize that they can demand far more than before. The authorities agreed to make concessions to the trade unions: wages were rising and working conditions were improving, but as soon as concessions were made, the working-class movement left the radicals without any support. Nevertheless, under the influence of the student movement, some workers found themselves inside the non-system opposition. In France, self-management and action committees emerged in May 1968 to become centers of resistance alongside student assemblies. In contrast to official trade unions, those were direct democracy organizations and not representative ones. When the wave of strikes subsided, the police easily wiped them out.

In Italy, with its syndicalist traditions, the non-system opposition was connected with the working-class movement far more tightly. It was in Italy that the strongest working-class protests followed student unrest. The hot autumn of 1969 was a clear reminder of the memorable Bienno Rosso period (Two Red Years), when Italy was on the brink of revolution. Factory committees, or local self-management organizations, were emerging at industrial plants and relied on the assemblies and workers' meetings of one industrial enterprise or workshop. The mission of the assemblies was to keep under control the factories' owners and management. Naturally, Italian businessmen and the authorities struggled with the system of committees, but 
neither arrests nor criminal prosecution (there were more than 10,000 cases against workers' delegates in 1970) yielded the desirable effect.

Italy had one more special feature in that the Italian Communist Party was the most independent of all Western Communist parties in relations with Moscow. Relying on a strong theoretical tradition (primarily on Antonio Gramsci's works), the Party was prepared to contact the non-system opposition. As a result of strikes, a special law on worker control was passed in 1970. In 1972-1973, collective bargaining agreements with industrialists, in fact, legalized factory committees. However, with time, factory committees began to merge with the system in the capacity of trade unions' grassroots organizations, which, on the one hand, guaranteed Italian workers far better conditions and, on the other, made them shift from seizures of enterprises to traditional forms of struggle (Drabkin, 1994, p. 83-84).

The special features of the working-class movement in Italy left an imprint on the terrorist organization called the Red Brigades. In their first years the Red Brigades committed terrorist attacks against factory officials, managers, and CEOs-those who aggressively opposed the development of assemblies and working-class control (one of the first operations by the Red Brigades was an explosion at Pirelli factories in 1970). This also explains the massive support for the Red Brigades. According to some estimates, more than 25,000 members were involved in their activities (in contrast, the RAF had dozens of members and hundreds of recruited supporters).

In France, at the moment Action Directe emerged, tough antiimmigration measures were being taken, not with the aim of putting an end to migration, but to keep migrants in an inferior position as cheap labor. France conducted active and aggressive neocolonial policies, particularly in Africa (the invasion of Chad in 1983 was far from the only example) and, lastly, supported all other NATO countries and the United States in the Cold War. Many founders of Action Directe in the 1970s took an active part in the struggle against the Franco regime in Spain, which, contrary to frequently repeated clichés, remained extremely harsh towards the opposition in its final days (Pozharskaya, 2010, pp. 336, 342). In fact, Puig Antich, one of the closest friends of 
Action Directe leader Jean-Mark Rouillan, was arrested and brutally executed in a Spanish jail (Manuel Huerga's film Salvador depicts the events of his life). The experience of the underground armed struggle against Nazism helped Action Directe members in their confrontation with the French government, whose activity they interpreted as latent fascism towards the colonies, migrants, and workers. The most highranking victim of Action Directe was George Besse, Renault's CEO, who fired more than 21,000 employees, cut wages, and conducted reprisals against workers. In all, more than 100 various operations were carried out in 1979-1987. The organization's membership numbered several thousand. Action Directe carried out acts of sabotage at weapons factories that manufactured military products to be exported for colonial wars against the population of "third world countries" (Tkachov, 2013).

The ultra-radicals failed to create a united anti-imperialist front. Attempts to persuade workers and migrants in Europe to rise up in revolt against neoliberal reforms led nowhere. Rouillan wrote: "Our slogan 'Return War Here!' was to let the proletarians of the third world see for themselves that in the metropolitan powers there exist not only high-fed Left and indifferent people helpless in the face of mass slaughter, arms trade and support for devastating wars. [...] This is most essential, and it should be demonstrated to the world" (Tkachov, 2013). In this sense the activity of left-wing radical groups indulging in urban guerilla warfare may be considered partially successful. But they failed to gain a mass base to rely on and had no chance to succeed in this respect. One reason was the deindustrialization of the West, when production was transferred to the "third world." Some trendy and incompetent politicians interpreted this as the emergence of a "postindustrial society." In Europe, the working class began to shrink, only to grow in the third world. Some European ultra-radicals took note of that, scrutinized this phenomenon, and decided that their main goal should be support for the revolutionary movement in the third world. The European working class, they argued, had turned bourgeois and became a recipient of certain dividends from exploiting the peripheral countries. Denmark's Blekingegadebanden (Blekinge Street Gang), as 
the media dubbed this group, staged a number of robberies in order to provide medical supplies and clothes to national liberation movements in Africa and Asia, including Zimbabwe, Mozambique, and Palestine (Dergunov, 2019, pp.242-245; Kuhn, 2014, pp.21-91). Also, its members were closely studying changes in the modern capitalist system. They believed that "in fact, the sole way of participation in the struggle for socialism for the people of imperialist countries was material support for the national liberation movements in the third world" (Dergunov, 2019, p. 245). The group's leaders, already imprisoned, said in the 1990s: "The story of the Blekingegade Group is a story about political action as a reaction to the political action of others. It provides an example of how to connect national and international politics. It is a story of anger at injustice and a will to change the world. It is a story about doing something, since doing nothing was not an option for us. It is a story about political analysis and about reflections on what is true and what is not. Global exploitation and inequality were the main causes of our political actions. As we know, global exploitation and inequality still exist" (Kuhn, 2014, pp. 91). This may sound like exotic revolutionary romanticism, but one of the group's leaders and bright Marxist thinker Torkil Lauesen dismissed such interpretation: "I object to our being painted as 'revolutionary romantics.' The real romantics were those who thought that the working masses of the imperialist countries would rise in rebellion" (Lauesen, 2018, p. 205). Although Lauesen's work bears a peculiar imprint of Euro-Maoism, by and large his analysis of the reasons for the European working class's conservatism and modern economic processes should be recognized as absolutely fair.

Leftist ultra-radicalism of the 1970s-1980s stemmed from the weakness of the mass left-wing movement, the awareness of the degradation of pro-Soviet mass Communist parties, the struggle against incorporation in the capitalist system at the cost of abandoning not only the Communist ideology, but the very ethics of the protest movement. Europe's urban guerillas were aware of the stark choice they were faced with: integrate with the capitalist system, turn into sect-like micro-organizations, or push ahead with their struggle. They found inspiration not so much in the historical examples of struggle 
in Europe as in the struggle in the "third world," which they tried to import back into the "first one" of Europe and the United States.

If it is not part of a powerful political movement, terror will inevitably force a group's participants to isolate themselves and become dogmatized, while the original goal will be gradually lost. The bravest, most devout and dedicated members of terrorist groups are the first to lose their lives. The members of Russia's Narodovoltsy (People's Will) were well aware of this, and this became one of the main reasons for the loss the Socialist Revolutionaries suffered after the February Revolution. They just did not have enough leaders equal in scale to those who died in the terror campaign to consolidate the party and retain power in 1917. In this sense the traditional SocialDemocratic criticism of individual terror turned out to be essentially fair for the 1970s and 1980s. But the participants in the European guerilla movement were unable to deal with their alienation under capitalism, the monstrous exploitation of peripheral countries, or the defeat of the Left. So they preferred to fight on.

Russia's left-wing political scientist Alexander Tarasov wrote on the eve of the previous anniversary of the Red May of 1968: "The main content of the new myth is already clear: 1968 is a 'victorious revolution,' which 'changed the face of capitalism' and made it extremely free, extremely democratic, extremely tolerant, and meeting the needs of the entire population, including the youth, women, and minorities" (Tarasov, 2008).

This myth is expected to somehow conceal the fact that the 1968 movement largely ended in failure. Without a revolution, the system emerged as the winner. Capitalism changed, but those were facelifting changes. Political stagnation and degradation of most left-wing movements were not the only effect of the political defeat. In the field of theory, the defeat was still graver. Depressed by the revolution's failure, structuralist thinkers saw the cause of this defeat and the source of the victory of the authorities in the language proper. As a result, they surrendered politically and theoretically. This conclusion, 
this pessimistic outcome of the "1968 revolution," literally paralyzed social philosophy until the end of the 20th century and considerably undermined the organizational and mobilizational potential of the left-wing movement.

Hungarian historian Tamás Krausz wrote: “The neoliberal turn was adorned by such feathers from the 1968 legacy as antiracism, multiculturalism, the protection of human rights and the rights of minorities, while society was stripped of opportunities for self-defense; 1968 and Keynesian ideas were abandoned and the logic of capital brought about an antisocial system of the free market, which praised to the sky social inequality. [...] In this way capital and its institutions in reality derived profit from anti-government aspirations of 1968, [...] the real aim was to restrict or totally eliminate not the state as such, but its social functions, its institutions and social welfare measures" (Krausz, 2009). The left-wing movement ceded both political initiative and intellectual hegemony, although in academic circles leftists almost constituted a majority.

It seemed that the triumph of the ideologists and practitioners of neoliberalism, which became obvious after the collapse of the Soviet Union, buried the prospects of the left-wing movement and, still more so, of the non-system movement. Most European leftists even lacked a set of theoretical instruments to properly analyze the demise of the Soviet Union. Francis Fukuyama in 1989 (just as Daniel Bell thirty years earlier) proclaimed "the end of history" and the victory of the liberal system. It looked like the non-system elements were devoured and digested by the system, but on January 1, 1994, when the North American Free Trade Agreement (NAFTA) took effect, the Zapatista Army of National Liberation (ZANL) launched an uprising in Mexico's southern state of Chiapas. In the summer of 1996 Chiapas hosted the first world meeting against "globalization," which heralded the beginning of the "anti-globalist" movement (Subcomandante Marcos, 2002, pp. 8-11, 125-130). The further march of events is well known: the emergence of social forums, a growing anti-globalist movement among "middle class" youth in the industrialized countries, antiglobalists' clashes with police in Seattle, Genoa, Prague, and Göteborg, and the appearance of social forums. But, as it was stated above, that 
movement never raised the issue of power and of changing the system of property, so it was doomed to inglorious oblivion. Neoliberal ideology and practice gained the upper hand once again. In the context of the left's weakness, different varieties of right-wing nationalism emerge as an alternative, with the European Parliament elections in May 2019 as the latest confirmation of this. Although the rightists managed to gain less strength than many analysts had anticipated, the left, in particular, the centrist left, lost votes once again. The entire political system shows stagnation and a lack of sound alternatives to neo-liberal practice, while most political forces remain ideologically vague (Smith, 2019).

A number of leftist old-timers, followers of the traditional Marxism of the first half of the 20th century, attempted to preserve the radical vector of the theory (provided radicalism is understood in accordance with Marx's well-known saying "To be radical is to grasp things by the root"). They include economists grouped around the magazine Monthly Review: Paul Baran, Paul Sweezy, Andy Higginbottom, and their successors, who scrupulously examined the processes of accumulating capital in modern globalized capitalism, Hungarian Marxist philosopher István Mészáros, a disciple of György Lukács, and theorists of peripheral capitalism Samir Amin, Teotónio Dos Santos, Giovanni Arrigi, etc. Odd as it may seem, their conclusions regarding the way modern monopolistic capitalism works are largely identical to those formulated in the process of their ultra-radical political activity and its subsequent analysis in prison by RAF members (Oni xotyat nas slomit', 2003), Action Directe, and Blekingegadebanden. Both were moving towards new approaches in the field of class theory by analyzing the global division of labor and forming a new working class in the "Global South." Neither managed to gain massive support from the left and still remain marginal in the political movement and in scholarly and theoretical discussions. But given the theoretical impasse where the traditional social-democratic parties and more radical left-wingers have found themselves and the fact that the free market ideology is discrediting itself to an ever greater extent and its criticism is becoming commonplace, one can forecast with a great degree of probability that this tradition will prove its relevance in the near future; in Europe, last of all. 
In the "Third World" the events of 1968 were neither the beginning nor the end of the revolutionary upsurge that started in the 1950s and is sandwiched between the Cuban revolution of 1959 and the Nicaraguan revolution of 1979. There were different stages of struggle, different heroes, and different leaders, who sometimes caused greater influence on the European Left than the other way around. In the "Third World" mass movements and mass struggle were underway against local dictators and Western neocolonialism, which claimed tens of thousands of lives. One of the lessons of the 1968 legacy that the abovementioned thinkers and revolutionaries learned is that the West ceased once and for all to be the source and center of anti-capitalist struggle. Torkil Lauesen, already quoted above, says that the working class of the Global North (Europe and the United States) may take part in this struggle, but hegemony will belong to the 1.5 billion proletarians ( 80 percent of the world's working class) concentrated in the Global South, mainly in China and India (Lauesen, 2018). It is hard to dispute this forecast today, although stubborn attempts to turn a blind eye to the "third world" still occur among left-wing authors (Kagarlitsky, 2017).

Long before the turbulent events of the 20th century Alexander Herzen came up with this diagnosis: "Conservatism that pursues no aim other than preserving the outdated status quo is as destructive as revolution. It destroys the old order not with the scorching fire of wrath, but with the slow fire of senility" (Herzen, 1956, p. 505).

A renowned researcher of American anarchism and African cultures, Nikolai Sosnovsky, is curt: "A system without anti-systemic elements falls into idiocy" (Sosnovsky, 1996). A large share of the 1968 legacy has become part of this system, so a new rise of the nonsystem left-wing opposition should be expected at least because the main problems that the participants in the 1968 movements and leftist radical groups of the 1970s and 1980s tried to resolve are still there. Despite the period of weakness and organizational and ideological degradation, the left-wing movement is capable of reviving itself and once again challenging capitalism, which is quickly losing its "human face." The effect of the facelift (in other words, ideological) operation that Western capitalism performed on itself after 1968 is about to end. 
Therefore, the experience (including the negative experience) of the 1968 generation cannot remain untapped. What this new upturn of the left-wing movement will look like and what role post-Soviet countries will play in it remains anyone's guess, but one thing seems indisputable: the main impetus of this new upturn will not come from Europe.

\section{References}

Baran, P., 1961. The Commitment of the Intellectual. Available at: https:// monthlyreview.org/1961/05/01/the-commitment-of-the-intellectual/ [Accessed 15 July 2019].

Böll H., 1996. Chto hochet Ul'rika Majnhof - pomilovaniya ili garantij bezopasnosti. [What does Ulrike Meinhof want - pardon or a guarantee of security?] In: Böll H. Collected Works, Vol. 5. Moscow: Hudozhestvennaya literatura, pp. 448-457.

Debord, G., 1990. Comments on the Society of the Spectacle. London, New York: Verso.

Dergunov, Yu.V., 2018. Prospects for Anti-Capitalism in a Divided World. Book Review: Lauesen T. (2018) The Global Perspective. Reflections on Imperialism and Resistance, Montreal: Kersplebedeb. Sociology of Power, 30 (4): pp. 242-256.

Dmitriev, A. N., 2004. Marksizm bez proletariata. Georg Lukach i rannyaya Frankfurtskaya shkola [Marxism without the proletariat. György Lukács and the early Frankfurt School]. Saint Petersburg: European University in Saint Petersburg.

Drabkin, Yu.S.(ed.), 1994. Social'nye dvizheniya na Zapade v 70-e i 80-e gg. XX veka. [Social Movements in the West in in the 1960s and 1970s]. Moscow: Institute of World History.

Harvey D., 2007. A Brief History of Neoliberalism. Oxford: Oxford University Press.

Herzen, A.I., 1956. O razvitii revolyucionnyh idey v Rossii. [On the History of Revolutionary Ideas in Russia]. In: Herzen, A.I. Sochineniya, Vol. 3. Moscow: GIHL, pp. 379-513.

Hobsbawm E., 1995. Age of Extremes. The Short Twentieth Century 1914-1991. London: Abacus.

Hobsbawm E., 2007. Revolutionaries. London: Abacus.

Hobsbawm E., 2017 Fractured Times. Culture and Society in the Twentieth Century. Moscow: AST. 
Jameson F., 2008. The Ideologies of Theory. London, New York: Verso.

Jaspers K., 1969. The Future of Germany. Chicago: Chicago University Press.

Kagarlitsky, B., 2017. Between Class and Discourse. How Left Intellectuals Serve Capitalism. Moscow: HSE Publishing House.

Krausz T., 2008. 1968 - mnogoobrazie istoricheskogo naslediya. Vostochnoevropejskij "sluchaj" [The Year 1968 - Diversity of Historical Legacy. The "Case" of Eastern Europe]. Scepsis. Available at: https://scepsis.net/library/ id_2357.html [Accessed 15 July 2019].

Kuhn, G. (ed.), 2014. Turning Money into Rebellion: The Unlikely Story of Denmark's Revolutionary Bank Robbers. Edited and translated by Gabriel Kuhn. Montreal: Kersplebedeb.

Kyonig, H., 2012. Budushchee proshlogo. Natsional-sotscializm v politicheskom soznanii FRG [The Future of the Past. National Socialism in FRG]. Moscow: ROSSPEN.

Laclau, E. and Mouffe, C., 1985. Hegemony and Socialist Strategy: Towards a Radical Democratic Politics. London: Verso.

Lauesen, T., 2018. The Global Perspective. Reflections on Imperialism and Resistance. Montreal: Kersplebedeb.

Lindsay, J.A., Boghossian, P. and Pluckrose, H., 2018. Academic Grievance Studies and the Corruption of Scholarship. [online] Available at: https:// areomagazine.com/2018/10/02/academic-grievance-studies-and-thecorruption-of-scholarship/ [Accessed 15 July 2019]

Lyotard, J.-F., 1984. The Postmodern Condition: A Report on Knowledge. Minneapolis: University of Minnesota Press.

Mann, M., 2012. The Sources of Social Power. Volume 4, Globalizations, 19452011. Cambridge University Press.

Marcuse, H., 2007. One-Dimensional Man. London, New York: Routledge Classics.

Marighella, C., 2002. Mini Manual of the Urban Guerrilla. [online] Available at: https://www.marxists.org/archive/marighella-carlos/1969/06/minimanualurban-guerrilla/index.htm [Accessed 15 July 2019].

Meinhof, U., 2004. Ot protesta k soprotivleniyu [From Protest to Resistance]. Moscow: Gileja.

Beseda, 2003. Oni xotyat nas slomit'. Beseda s politzaklyuchennymi - boictsami $R A F$ [They Want to Subdue Us. Conversation with RAF Political Prisoner 
Activists] [online] Available at: https://vk.com/@-27569095-oni-hotyat-nasslomit-beseda-s-politzakluchennymi-boicami-ro [Accessed 20 July 2019].

Pozharskaya, S.P., 2010. Francisko Franko i ego vremya [The Times of Francisco Franco]. Moscow: OLMA Media Group.

Rouillan, J.-M., 2013. Nashe delo protiv ix del [Our Cause against Theirs]. [online] Scepsis. Available at: https://scepsis.net/library/id_3365.html [Accessed 15 July 2019].

Smith, A., 2019. European Parliament Elections: 5 Takeaways from the Results. NBC News, 27 May [online]. Available at: https://www.nbcnews.com/ news/world/european-parliament-elections-5-takeaways-results-n1010491 [Accessed 15 July 2019].

Sokal, A. and Bricmont, J, 2003. Intellectual Impostures. Postmodern Philosophers' Abuse of Science. London: Profile Books.

Sosnovsky, N., 1996. Prognoz pogody na zavtra i vchera [Weather Forecast for Tomorrow and Yesterday]. [online]. Available at: http://margenta.ru/ZabriskiRider/stati-nikolaya-sosnovskogo-iz-raznih-nomerov-ZR/prognoz-pogodina-zavtra-i-vchera/ [Accessed 15 July 2019].

Subcomandante Marcos, 2002. Another Revolution. Moscow: Gileja.

Tarasov, A.N., 2003. Vietnam blizko ili partizanskaya voina na beregakh Reyna [Vietnam Is Close By, Or a Guerilla War on the Banks of the Rhine]. [online]. Scepsis, No.1. Available at: https://scepsis.net/library/id_658.html [Accessed 20 July 2019].

Tarasov, A.N, 2008a. 1968 god v svete nashego opyta [The Year 1968 with Regard to Our Experience]. [online]. Scepsis. Available at: http://scepsis.net/ library/id_2274.html [Accessed 15 July 2019]

Tarasov, A.N., 2008b. Afiny: Evropeysky antiglobalizm v tupike [Athens: European Anti-Globalism in a Deadlock]. Scepsis, No.5, pp. 23-31.

Tkachov, P., 2013. Action Directe: zamalchivayemy opyt polnomashtabnoi gorodskoi geril'i [Suppressed Experience of a Full-Scale Guerilla War]. [online]. Scepsis. Available at: https://scepsis.net/library/id_3366.html [Accessed 15 July 2019].

Vaneigem, R., 2001. The Revolution of Everyday Life. London: Rebel Press.

Wallerstein, I., 1996. Historical Capitalism with Capitalist Civilization. London, New York: Verso.

Žižek, S., 2008. The Sublime Object of Ideology. London, New York: Verso. 